\title{
Children's Digital Game Addiction and Opinions About Their Parents' Playing Digital Games ( A Mixed Method Study)
}

\author{
Zekihan Hazar \\ Correspondence: Zekihan Hazar, Niğde Ömer Halisdemir Universty School of Physical Education and Sports, Turkey
}

Received: November 21, 2018

Accepted: December 12, 2018 Online Published: December 13, 2018

doi:10.11114/jets.v7i1.3785

URL: https://doi.org/10.11114/jets.v7i1.3785

\begin{abstract}
The purpose of this research is to review the level of children's digital game playing addiction and to evaluate their opinions on the parents playing digital games. In the 2017-2018 academic year, the students of the Şehit Ramazan Konuş secondary school affiliated to the Niğde Provincial Directorate of National Education constitute the universe of the research. 246 students who were chosen according to the method of typical case sampling constituted the sampling of the research. "Mixed method research" has been adopted as a research model and "Explanatory Design" has been used as a mixed method research design.

In this direction; the "Digital Game Addiction Scale for Children" developed by Hazar and Hazar was applied in 2017 in the quantitative part of the study. In the qualitative section, interviews were made with 14 participants, 7 females and 7 males, who had high level of addiction and who regularly played digital games, participated in the research voluntarily. The data were analyzed by content analysis and descriptive analysis.

The data obtained for the study were analyzed primarily through the SPSS 24 packet program. According to the results of this analysis, participants were found to have statistically significant difference in gender, age, and parents' playing and not playing digital games, while it was seen that there was no statistically significant difference. Whether they had a sportsman license, whether or not internet access was available at their residence, and parents' educational status variables In the qualitative analysis of the research, 8 themes and sub-themes related to this theme were formed.

As a result; it is a striking result that the dependency of the participants with digital game playing parents and weak family relations is higher than the other participants. The high level of addiction of the participants with an athlete license is a noteworthy finding.
\end{abstract}

Keywords: game, digital game, addiction, sport, parent

\section{Introducton}

It can be said that the level of anxiety increases with the increasing awareness of parents on the subject, either directly or indirectly experiencing the negative consequences of digital games that have become an important part of children's daily life $(27,21,9,17,15,23,11)$. However, one of the most important points that parents are not aware of is that the model behaviors they exhibit (digital play behavior) can motivate the children more in these games. For example; the parents who make efforts to limit the duration and content of the play and who constantly warn about the drawbacks that these games may cause, as well as the fact that they play these games intensively, cause children to experience a contradiction in this regard and this situation may sometimes turn into a conflict.

Toran et al. (28), states that the first experiences of children's digital games are usually realized by the presentation of parents. On the basis of this finding, it can be said that children first met their parents through the use of digital game addiction, which is an important type of behavior addiction. İşçibaşı (15), states that parents have not been successful enough in this regard, although they have used many different methods to move their children away from digital games or limit play time and content. Öztütüncü Doğan (24), on the other hand, states that the digital play contents of children should be controlled by parents because the elements such as violence and sexuality in games adversely affect the children's social environment but adversely affect their brain development and lead to aggressive behaviors. All these determinations are important factors that push children to digital game addiction.

It is a fact that digital gaming addiction affects many people regardless of the demographic characteristics. However, childhood is the period when individuals are most prone to substance and behavioral addictions. Akçayır (2), states that 
individuals aged 11-14 years are more vulnerable than adults because of their developmental characteristics, cognitive, affective and physiological, and therefore more affected by digital games than adults. However, children who have poor relationships with their parents, who lack adequate attention and support, are deprived of parental guidance and protection during this critical period may also be one of the important factors leading children to this addiction. At this point, the evaluation of parents from the eyes of the children is very important in illuminating a critical aspect of this problem. In the literature review, it was seen that a significant part of the researches about the subject were aimed at examining the parents and expert opinions $(24,25,15,1,14,10,28,13)$. But; It is an important issue to be investigated whether children play these games in houses with more basic living space and parents who are role-model for children in these environments do not motivate their children with these behaviors.

The purpose of this study is to investigate the levels of digital game addiction of children according to various variables, especially to find out how these addicted children whose parents regularly play digital games evaluate their behaviors and what might be their effect on being addicted to games.

\section{Method}

This section of the study includes information on the analysis of the working group and data.

In this research, mixed method research was used. Mixed method research is a research that allows data collection, analysis and integration with qualitative and quantitative methods (31). Yıldırım and Şimşek (31) state that the most important feature of mixed method research is to use the data gathered by different methods to confirm each other and to ensure that the results of the research are more reliable and valid. In this context, "Explanatory Design" which is one of the mixed method research designs was used in the research. In the explanatory design, researchers first collect and analyze quantitative data and then collect qualitative data to complete and refine this data.

\subsection{Research Universe and Sample}

This study consists of the students studying in Şehit Ramazan Konuş Middle School in the 2017-2018 academic year. In the study, 'Typical sampling method' was used. The typical case sampling method involves collecting information on this sample by identifying a typical situation from the large number of cases in the universe related to the research problem (3). In this context, the sample of the research consists of a total of 206 students including 104 females and 142 males.

\subsection{Process}

Data were collected by using the survey method in the quantitative part of the study. Survey is a research approach that aims to define a situation that exists in the past or at the moment as it does. Whatever the subject of the study is, there is no attempt to change and influence them. The aim is to observe and determine the correct thing. The main goal is to observe without trying to change (16). In this context, Digital Game Addiction Scale for Children "was applied to the participants. In the qualitative part of the research, semi-structured interview method was used. Interview is one of the most common data collection methods used in qualitative research since it is strong in terms of determining the emotions, thoughts and experiences of participants based on speech (31). In the semi-structured interview method, the interview guide includes semi-structured interview questions. The questions are flexible and usually collect specific data from each participant. There are no predetermined expressions and question answers. In this context, qualitative data were collected by conducting interviews with a total of 14 participants ( 7 females and 7 males) who agreed to participate voluntarily from the participants who had a high level of addiction (scale total score of 49 and above) and whose parents regularly play digital games (every day). (In the qualitative part of the study, the main reason for limiting the number of participants to 14 people is that the participants with high level of dependence do not want to volunteer in this process. Therefore, only 14 participants were included in the qualitative part of the study. This is an important limitation of the research).

\subsection{Data Collection Tools}

The "digital game addiction scale for children" used in the research consists of four sub-factors. The Cronbach Alpha coefficients of the sub factors were found to be .75 for the first sub-factor, .80 for the second sub-factor, .72 for the third sub-factor, .56 for the fourth sub-factor and .88 for the total sub-factor. A 5-point Likert-type scale was used in evaluating the expressions in the measure $(1=$ Never, $2=$ Not agreeable, $3=$ Undecided, $4=$ Agree, $5=$ Completely agree). Factors; Excessive Focus and Conflict on Playing Digital Game, Tolerance Development in Game Play and Value Added to Game, Postponement of Individual and Social Duties / Assignments, Psychological-Physiological Reflection of Dysnity and Diving in Game. The reliability coefficient for this study was 88 .

Personal information form: In personal information form, variables such as gender, sporting, parent play status, age, parent education status which are thought to be related to research results, are included. (In the literature review, it is stated that the levels of digital game dependency of the people who are actively engaged in sports are lower than those who do not. For this reason, "athlete license" variable is included in the research in order to identify individuals who are actively engaged in sports). 
The questions in the qualitative part of the study were prepared by literature review and the opinions of two experts in the field of physical education and sports sciences (phd.).

The questions are as follows;

1. What time do parents most often play digital games?

2. What kind of activities do you do with your parents in your free time?

3. How does the digital game play of parents affect your relationship?

4. Would you want the parents to set the time spend on playing digital games?

5 . What would you like to tell your parents about playing digital games?

\subsection{Analysis of Data}

As a result of the literature review, the variables that were thought to be related to the results of the research were determined and analyzes were made about these variables. The collected data were analyzed with SPSS 24 package program. In the analysis of the scores related to the variables, Mann-Whitney U tests were used with t-test in pairwise comparisons and One-Way ANOVA tests were used for multiple comparisons. In the analysis of qualitative data, descriptive and content analysis methods were used. In this process, along with the predetermined themes, coding was applied in the analysis of the data, meaningful sub-themes and main themes were obtained from the codes. In order to provide evidence for the reliability of the research, direct quotations of the participants' answers to the research questions are given. Another application related to the reliability of the research is the consensus among the experts and the calculations related to the disagreement. The reliability of the study was calculated by determining the number of consensus and number of opinions in the comparisons and by the reliability formula proposed by Miles and Huberman (22) $($ Reliability $=$ Consensus Union $/($ Consensus + Opinion $) \times 100)$. The reliability coefficient was found to be 96 . The consensus or disagreement of the field experts has emerged especially in the theme and sub-themes.

\section{Results}

The analysis and results of the data obtained in this section of the research are given.

Table 1. Results of t-test for Gender Variable of Participants

\begin{tabular}{|c|c|c|c|c|c|c|}
\hline Scale scores & Gender & $\mathbf{N}$ & Mean & Sd & $\mathbf{t}$ & $\mathbf{P}$ \\
\hline \multirow{2}{*}{ Total Score } & Female & 104 & 43,7596 & 14,77369 & \multirow{2}{*}{$-4,511$} & \multirow{2}{*}{,00 } \\
\hline & Male & 142 & 54,5704 & 20,90892 & & \\
\hline \multirow{2}{*}{ 1. Sub-factor } & Female & 104 & 11,8269 & 4,48177 & \multirow[b]{2}{*}{$-4,241$} & \multirow{2}{*}{,00 } \\
\hline & Male & 142 & 15,1268 & 6,94442 & & \\
\hline \multirow{2}{*}{ 2. Sub-factor } & Female & 104 & 13,3654 & 5,00108 & \multirow{2}{*}{$-4,892$} & \multirow{2}{*}{,00 } \\
\hline & Male & 142 & 17,0704 & 6,42871 & & \\
\hline \multirow{2}{*}{ 3. Sub-factor } & Female & 104 & 9,6154 & 4,00317 & \multirow[b]{2}{*}{$-3,200$} & \multirow[b]{2}{*}{,00 } \\
\hline & Male & 142 & 11,6408 & 5,46860 & & \\
\hline \multirow{2}{*}{ 4. Sub-factor } & Female & 104 & 7,2885 & 2,74365 & \multirow{2}{*}{$-2,624$} & \multirow{2}{*}{,00 } \\
\hline & Male & 142 & 8,3873 & 3,56669 & & \\
\hline
\end{tabular}

When Table 1 is examined, it is seen that the total scores taken by the participants from the digital game addiction scale for the gender variable are in favor of the male participants and this difference is statistically significant.

Table 2. Results of Mann-Whitney U Test for Participants to Have an Athlete License

\begin{tabular}{|c|c|c|c|c|c|}
\hline Scale scores & Athlete license & $\mathbf{N}$ & Sum of Rank & $\mathbf{Z}$ & $\mathbf{p}$ \\
\hline \multirow{2}{*}{ Total Score } & Have & 81 & 126,87 &,- 521 &, 60 \\
\hline & Not Having & 165 & 121,85 & & \\
\hline \multirow{2}{*}{ 1. Sub-factor } & Have & 81 & 121,79 &,- 265 & $\mathbf{7 9}$ \\
\hline & Not Having & 165 & 124,34 & & \\
\hline \multirow{2}{*}{ 2. Sub-factor } & Have & 81 & 126,14 &,- 408 & ,68 \\
\hline & Not Having & 165 & 122,21 & & \\
\hline \multirow{2}{*}{ 3. Sub-factor } & Have & 81 & 127,52 &,- 625 &, 53 \\
\hline & Not Having & 165 & 121,53 & & \\
\hline \multirow{2}{*}{ 4. Sub-factor } & Have & 81 & 129,27 &,- 897 & ,37 \\
\hline & Not Having & 165 & 120,67 & & \\
\hline
\end{tabular}

When Table 2 is examined, it was determined that the total scores obtained from the digital gaming addiction scale of the participants who had an athlete license did not show a statistically significant difference. 
Table 3. Results of the Mann-Whitney U Test for The Parents of Participants to Play Digital Games

\begin{tabular}{|c|c|c|c|c|c|}
\hline Scale scores & Parent play status & $\mathbf{N}$ & $\begin{array}{c}\text { Sum of } \\
\text { Rank }\end{array}$ & $\mathbf{Z}$ & $\mathbf{P}$ \\
\hline \multirow{2}{*}{ Total Score } & Playing & 52 & 157,60 & $-3,967$ & ,00 \\
\hline & Not playing & 193 & 113,68 & & \\
\hline \multirow{2}{*}{ 1. Sub-factor } & Playing & 52 & 153,69 & $-3,530$ & ,00 \\
\hline & Not playing & 193 & 114,73 & & \\
\hline \multirow{2}{*}{ 2. Sub-factor } & Playing & 52 & 154,88 & $-3,662$ & ,00 \\
\hline & Not playing & 193 & 114,41 & & \\
\hline \multirow{2}{*}{ 3. Sub-factor } & Playing & 52 & 153,19 & $-3,484$ & ,00 \\
\hline & Not playing & 193 & 114,87 & & \\
\hline \multirow{2}{*}{ 4. Sub-factor } & Playing & 52 & 142,48 & $-2,248$ & ,02 \\
\hline & Not playing & 193 & 117,75 & & \\
\hline
\end{tabular}

When Table 3 is examined, it is seen that the addiction scores of the participants who play digital games are high and this difference is statistically significant.

Table 4. ANOVA Results of Age Variable of Participants

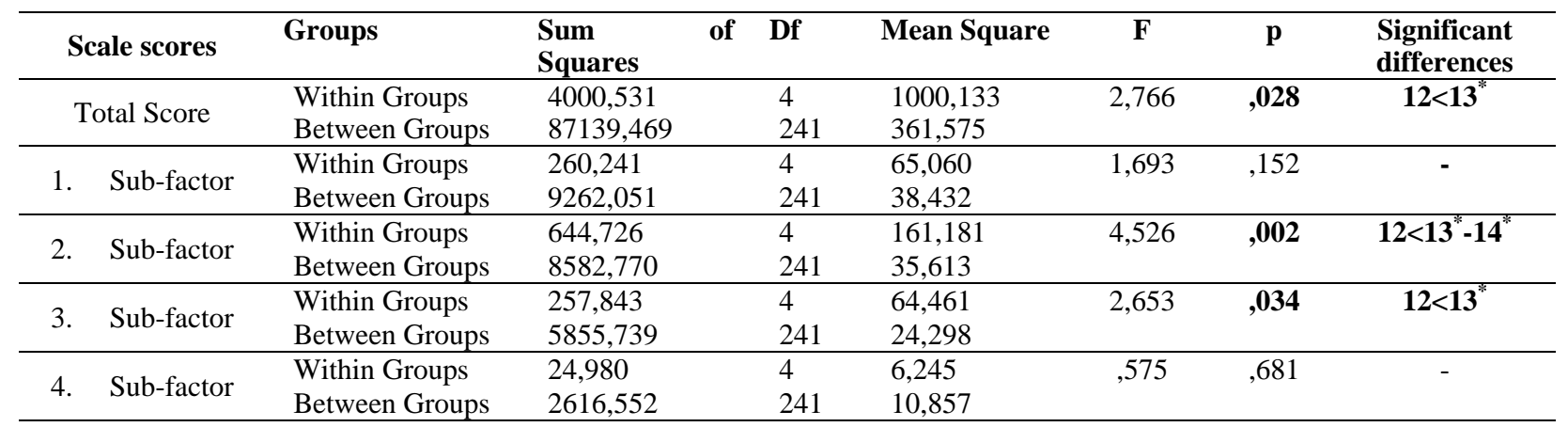

"The groups that are in favor of the score average are indicated by $(*)$ "

When Table 4 is examined, it was determined that the total score of the participants and the points they got from the second and third sub-factors showed a statistically significant difference in favor of 13 and 14 year-olds.

Table 5. Results of ANOVA Related to Mother Education Variable of Participants

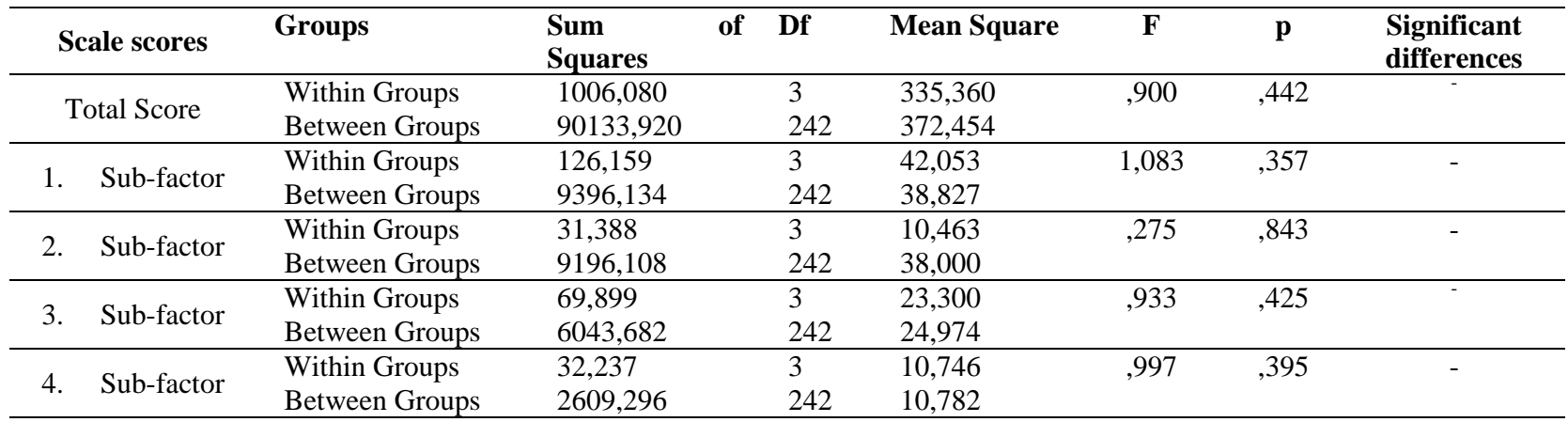

When Table 5 is examined, it was determined that the scores of the participants with different mother education level (primary, secondary, high school, university) did not differ statistically.

Table 6. ANOVA Results of The Father's Education Variable of The Participants

\begin{tabular}{|c|c|c|c|c|c|c|c|}
\hline Scale scores & Groups & $\begin{array}{l}\text { Sum } \\
\text { Squares }\end{array}$ & Df & Mean Square & $\mathbf{F}$ & $\mathbf{p}$ & $\begin{array}{l}\text { Significant } \\
\text { differences }\end{array}$ \\
\hline \multirow{2}{*}{ Total Score } & Within Groups & 668,508 & 3 & 222,836 & ,596 & 618 & \\
\hline & Between Groups & 90471,492 & 242 & 373,849 & & & \\
\hline \multirow{2}{*}{1.} & Within Groups & 93,989 & 3 & 31,330 & ,804 & ,493 & - \\
\hline & Between Groups & 9428,303 & 242 & 38,960 & & & \\
\hline \multirow{2}{*}{ 2. Sub-factor } & Within Groups & 44,374 & 3 & 14,791 & ,390 & ,760 & - \\
\hline & Between Groups & 9183,122 & 242 & 37,947 & & & \\
\hline \multirow{2}{*}{ 3. Sub-factor } & Within Groups & 27,770 & 3 & 9,257 & ,368 & ,776 & - \\
\hline & Between Groups & 6085,811 & 242 & 25,148 & & & \\
\hline \multirow[b]{2}{*}{4.} & Within Groups & 11,750 & 3 & 3,917 & 360 & 782 & - \\
\hline & Between Groups & 2629,783 & 242 & 10,867 & & & \\
\hline
\end{tabular}

When Table 6 is examined, it was determined that the scores of the participants in terms of father education 
level(primary school, secondary school, high school, university) were not statistically different.

\subsection{Qualitative Findings}

Table 7. What time do parents most often play digital games? question-answer analysis

\begin{tabular}{lc}
\hline Time period & $f$ \\
\hline Sitting with family members (in the living room -kitchen) & 9 \\
While watching TV & 4 \\
Bedtime (before sleep) & 3 \\
\hline
\end{tabular}

When the table is examined, the participants stated that their parents played these games mostly with their family members (in the living room - in the kitchen), while watching TV and Bedtime (before sleep).

Table 8. What kind of activities do you do with your parents in your free-time? Answer analysis.

\begin{tabular}{|c|c|c|c|}
\hline Theme & Sub Themes & Codes & $f$ \\
\hline \multirow{3}{*}{ Leisure Activities } & Outdoor Activities & $\begin{array}{l}\text { Shopping } \\
\text { Going to cinema }\end{array}$ & $\begin{array}{l}3 \\
2 \\
6\end{array}$ \\
\hline & & $\begin{array}{l}\text { Watching TV } \\
\text { Eating }\end{array}$ & $\begin{array}{l}6 \\
4\end{array}$ \\
\hline & Household Activities & Various games & $\begin{array}{c}3 \\
18\end{array}$ \\
\hline
\end{tabular}

When the table 8 examined, it is seen that the answers of the participants were classified as outdoor Activities and indoor activities. Participants' expressions are given below as an example of the answers of the participants to this research question. For example;

Participant M.A: Usually we go for a ride, or go to the cinema, shopping.

Participant O.E: We are watching television or playing some games.

Table 9. How does the digital game play of parents affect your relationship? Answer analysis of the question

\begin{tabular}{|c|c|c|c|}
\hline Theme & Sub Themes & Codes & $f$ \\
\hline \multirow{2}{*}{ Positive Impact } & \multirow{2}{*}{ Common Share } & They're playing my friend & 1 \\
\hline & & We share happiness and success together & 1 \\
\hline \multirow{7}{*}{ Negative Effect } & \multirow{5}{*}{$\begin{array}{l}\text { Decrease in Domestic } \\
\text { Communication and Conflict }\end{array}$} & We are having a communication break & 4 \\
\hline & & They are negative examples & 3 \\
\hline & & Discussing about playing games & 3 \\
\hline & & They don't empathize with me & 2 \\
\hline & & They're so into the game & 2 \\
\hline & \multirow{2}{*}{ Blocking Academic Success } & I cannot study & 4 \\
\hline & & They don't help me with my homework & 2 \\
\hline \multirow{3}{*}{ Neutral } & \multirow{3}{*}{ Be Irresponsive to } & Because they're playing little & 1 \\
\hline & & They are playing while lying & 1 \\
\hline & & Total & 24 \\
\hline
\end{tabular}

Table 9. When examined, it is seen that the answers of the participants are more negative and neutral. Participants' expressions are given below as an example for the answers of the participants to this research question. For example;

Participant S.D: We play the same game with my mother. Sometimes he loves me when I find the word he can't find. It's very enjoyable to play together.

Participant A.T: They come home from evening to evening, then we can not talk too much because they are playing. Because they don't have a conversation because they buried their heads.

Participant H.A: There is a lot of noise from the phone and television, and I cannot study.

Participant G.N: I think it does not affect. It does not affect in any way because he/she plays less. 
Table 10. Would you like parents to set the time spent on digital games for you? Answer analysis of the question

\begin{tabular}{|c|c|c|c|}
\hline Theme & Sub Themes & Codes & $\boldsymbol{F}$ \\
\hline Positive & Common Activity Request & I would love to play real games together. & 4 \\
\hline \multirow[t]{4}{*}{ Approach } & & I would love to go to the movies together. & 2 \\
\hline & & I would love to chat. & 2 \\
\hline & Seeking attention and support & I would like them to help me with my homework. & 4 \\
\hline & & I would like them to ask how my day went. & 3 \\
\hline \multirow{6}{*}{$\begin{array}{l}\text { Negative } \\
\text { Approach }\end{array}$} & Acting independently & I wanted to be free in the games I played. & 3 \\
\hline & & I would like to hang out myself. & 3 \\
\hline & & I would like to play unlimited. & 3 \\
\hline & Empathy & Because it is their right to have fun. & 4 \\
\hline & & They are comfortable too. & 1 \\
\hline & & They should rest too. & 1 \\
\hline \multirow[t]{2}{*}{ Unstable } & Uncertainty & It does not matter to me & 4 \\
\hline & & Total & 34 \\
\hline
\end{tabular}

When Table 10 is analyzed, it is seen that the answers of the participants are gathered under more negative and unstable themes. Participants' expressions are given below as an example of the answers of the participants to this research question. For example;

Participant B.C: We can play games with them.

Participant Ü.Y: Yes, I would like to. I wish they could help me with my homework.

Participant M.A: No. My mother and dad are getting involved in every decision I want to make my own decision, so everybody take time. And they're always gonna study.

Participant C.D: They are interested in me whether they play games or not.

Table 11. What would you like to say to your parents about playing digital games? answer analysis of the question.

\begin{tabular}{cllc}
\hline Theme & \multicolumn{1}{c}{ Sub Themes } & \multicolumn{1}{c}{ Codes } & $f$ \\
\hline \multirow{3}{*}{ Free } & \multirow{2}{*}{ Limitation in Game Time } & Don't overdo it. & 4 \\
Approach & & Give me more time. & 4 \\
& & They need to reduce game time. & 4 \\
\cline { 2 - 3 } & \multirow{2}{*}{ Desensitization } & I want them to play the same games. & 2 \\
& & It doesn't impress me. & 1 \\
& & Total & $\mathbf{1 5}$ \\
\hline
\end{tabular}

Table 11 shows that all of the participants stated that their parents continue to play their digital game-playing behaviors, but they consider this situation under two different headings. For example, participants in the dimension of "Limitation in Play Time" used the following statements;

Participant H.D: I would like them to play enough so I would like them to relax.

Participant I.E: I wish they didn't play too much. Let them play, but they play with me. Mom, can you spare me some time and play with me?

Participants used the following statements to be considered as depersonalization;

Participant O.E: They play, but they don't move me, I think I should play too.

Participant M.I: I would like to play more because I feel bored in the games alone.

\section{Discussion and Conclusions}

With respect to the "Gender" variable which is the first sub-problem of the study, it was found that male participants' total scale scores and sub-dimension average scores are higher and that the difference is statistically significant. The main reason for this difference may be the fact that digital games are more appealing to male individuals in terms of content and accessibility (gaming arcades etc.). When the literature is examined, while it is seen that digital games are more of a male-dominated game type, similar results were found in other research studies (5, 7). For example, Wallenius and Punamäki (29), found that male students play violent video games more than female students in their study entitled "Digital Game Violence and Direct Aggression in Adolescence: A Longitudinal Study of the Roles of Sex, Age, and Parent-Child Communication". In another study entitled "Problematic computer game use (digital game) among adolescents, younger and older adults", Festl, Scharkow and Quandt (6) concluded that the levels of addiction to video games for men are significantly higher than that of women.

Regarding the second sub-problem of the study, which is whether the participants "have an athlete license", it was found that those who have athlete licenses have higher total and sub-dimensional scores on the digital game addiction scale, however, the difference is statistically insignificant. Interestingly enough, although it is mentioned in the literature that 
sports and exercising is one of the primary methods in coping with substance and behavioral addictions, $(4,20,30,11)$ the findings of this study point to the opposite direction. For example, in their study entitled "Recovery from addiction and the potential role of sports", Landale and Roderick (25) state that addict people had been stimulated into sports to explore the impacts of sports on the struggle against addiction in the "second chance" project conducted within the scope of alcohol and substance addiction in the UK. In the interviews, emphasizing the socialization effect of sports, the participants stressed that their inter-familial relationships got better, they acquired new friends, they were relieved from boredom and thus the thought and practice of using alcohol and substance increasingly became trivial in their lives. They also underlined the fact that they felt both physically and mentally better and their sense of self-sufficiency was enhanced thanks to sports. However, one of the main reasons that the results of this study contradict with the situation could be the fact that individuals dealing with sports use digital games as a sort of mental training tool. It is an observed common behavior that especially football games, that is one of the most popular digital games, are used by several athletes to get assistance in developing tactics in real games. In a similar study, Hazar, Mamak, and Çınar (12) found that individuals with athlete licenses have higher levels of digital game addiction in comparison to those who don't have licenses.

Regarding the third sub-problem of the study, which is whether the participants' "parents play digital games", it was found that those whose parents play games on a daily basis (every day) have higher total scores on the digital game addiction scale and that the difference is statistically significant. One of the most important reasons behind this result is that children pattern themselves after their parents' behaviors whom they take as role models and mimic them. It is likely that one of the key motivating factors driving children to play these games is the parents who are playing these games. Toran et al. (28) state that parents are the most important individuals who motivate their children to play digital games by introducing them to these games. Tortan et al., In their research, found that children who play intensively digital games have a role model, especially their parents. However, when the responses given by the participants to one of the qualitative questions of the study which is "in which period of time do your parents mostly play digital games?" is examined (Table 7), it is seen that parents mostly play these games when "Family members are around (in the living room-kitchen) $(f=9)$, watching $T V(f=4)$, or in the bed (before sleeping) $(f=3)$ ". According to these results, it can be argued that the game playing behavior exhibited by parents, who are the individuals whom the children spend most of their time with, motivate children for these games and tempts them to play as well; therefore, the parent factor is an important variable in these children's having higher levels of addiction. Although the literature suggests that the most important way to cope with addiction is to motivate individuals for sportive, cultural and arts activities, when Table 8 is examined, it is seen that the participants have more daily routine activities with their parents "Outdoor activities: Shopping $(f=3)$, Going to the cinema $(f=2)$. Household Activities: Watching television $(f=6)$, eating $(f$ $=4)$, playing games such as blind man's buff, hide and seek, etc. $(f=3)$ ". The fact that the activities between the parents and children are limited to these, may be an important factor in explaining the high levels of digital game addiction among these children. When Table 9 is examined, it is rather remarkable to find that when the participants answer the question of " How does your parents' playing digital games affect your relationship?" only 4 participants replied the question indicating a Positive Impact $=$ Meeting in a common denominator $(f=2)$, Not affected $(f=2)$ while a total of 20 participants underscored a Negative effect with two sub-dimensions $=$ Decrease in family communication $(f=14)$ and Prevent academic achievement $(f=6)$. For example, participant A.T states that: They are only home at nights, and we cannot talk much because they are playing games. We cannot have any conversations because they are so busy playing with their games. Sarah et al. (25) contend that parents develop several strategies to control the digital game behaviors of their children and one of the most remarkable of these strategies is the "co-operator" strategy. Some of the scholars examining this quite controversial strategy state that the co-operator strategy involves parents' playing together with the children to control the games the kids are playing and it has certain advantages such as having time together, meeting on a common denominator and taking over the reins during this time. Yet, the scholars who take the opposite side reject this strategy arguing that it may better motivate parents and children for such kind of games and therefore may yield negative outcomes.

Regarding the "Age" variable which is the fourth sub-problem of the study, the children of 13 and 14 age groups were found to have higher total scale scores as well as second- and third-dimension scores, and that these differences are statistically significant. The main reasons behind this situation may be because the participants of the 13-14 age groups behave more independently from their parents and spend more time playing digital games in comparison to the 12 age group, and because the older age groups have met with these games earlier and have spent more times on digital games than the younger group. From a different aspect, when Table 10 in the qualitative part of the study is examined; when the answers to the question of "Would you like your parents to allocate for you the time they spend playing digital games? " analyzed, the results are found to be: "Positive Approach= demand for common activities $(f=8)$, quest for support and care $(f=7)$ "and "Negative Approach = to be able to hang around Independently $(f=9)$, Empathizing $(f=6)$ and Uncertainty $(f=4)$ ". These results reveal that nearly $50 \%$ of the participants do not want to spend time with their parents. These findings coincide with the finding that older age groups want to behave more independently that is found in the quantitative part of this study given the "developmental age characteristics" addressed in the literature. For example, participant M.A states in response to the question of: "would you like your father or mother to allocate for 
you the time they spend on playing digital games?" "No. Mom and dad interfere with every decision I make, I'd like to make my own decisions, so it's like let everyone has their own time". The literature found a positive association between the time allocated for games and game addiction $(27,10,8,21,1)$.

Non-statistically significant differences were found between the total scale scores of the participants with respect to the "father's education and mother's education" variables that are the fifth and sixth sub-problems of the study. It can be observed in our everyday lives that regardless of their educational levels, today, almost all parents play these games to a certain extent. Furthermore, research (13) found that the level of awareness among most parents is rather low in terms of the negative outcomes that digital games might engender. Therefore, it can be argued that the finding that the digital game addiction levels of the participants do not differ significantly by the education level of their parents might result from this very fact.

When responses to the question of "what would you like to say to your parents about their playing digital games?" which took part in the qualitative part of the study and was the last question are analyzed, it is seen that the participants demonstrate a "Libertarian" approach towards their parents and that they exhibit this approach in two sub-dimensions. The participants who are considered in the first sub-dimension that was named as Limiting the Playing Time $(f=12)$ stated that their parents should limit their playing behaviors according to certain criteria. For example, participant I.E states that: I wish they didn't play too much. They can play, but they should play less and take care of me more. Mom, would you spare some of your time for me and play with me?

Participant K.P expresses that $I$ think they'd better play fewer games, I mean it is unnecessary. They'd better spend more time with us. Another interesting sub-dimension is the one that can be seen as Nonchalance $(f=3)$. For example, participant $\mathbf{O}$. E states that: They are playing, yet aren't letting me play. I mean it's better when both they play and let me play too". This finding is noteworthy in terms of showing that the relationship between the parent and child is not questioned and a family structure which is independent and nonchalant of one another is formed. In their study entitled "Awareness of risk factors for digital game addiction", Kneer, Rieger, Ivory, and Ferguson (18) found that "bad family background" is a significant factor in digital game addiction.

In conclusion, it comes out as a remarkable finding that especially the participants whose parents regularly play digital games and whose parental relationships can be considered weak have higher addiction levels in comparison to other participants. However, directing children to sports-exercise is one of the most effective ways to deal with this problem. At this point, physical education and sports hours should be increased both in schools and various trainings should be organized in order to inform parents.

The most important limitation of this study is the limited number of participants, especially in the qualitative part. However, despite 20 participants accepted to voluntarily participate in the study at the outset, 6 of them gave up in the following process. This limitation should be taken into consideration in future studies. In addition, the research question can be addressed in a more comprehensive manner by conducting interviews with parents and utilizing the observation method in future studies.

\section{References}

Akçay, D., \& Özcebe, H. (2012). Evaluation of Computer Game Playing Habits of Children at Pre-School Education Levels and Their Families. Journal of Child, 12(2), 66-71. https://doi.org/10.5222/j.child.2012.066

Akçayır, G. (2013). Health effects of digital games. Ankara: Pegem Akademi.

Büyüköztürk, Ş., Kılıç, Ç. E., Akgün, Ö. E., Karadeniz, Ş., \& Demirel, F. (2016). Scientific research methods. Ankara: Pegem Akademi.

Davis, R. A. (2001). A cognitive-behavioral model of pathological Internet use. Computers in Human Behavior, 17(2), 187-195. https://doi.org/10.1016/S0747-5632(00)00041-8

Demirtaş-Madran, H. A., \& Ferligül-Çakılcı, E. (2014). The relationship between agression and online video game addiction: a study on massively multiplayer online video game players. Anatolian Journal of Psychiatry, 15(2), 99-107. https://doi.org/10.5455/apd.39828

Festl, R., Scharkow, M., \& Quandt, T. (2016). Problematic computer game use among adolescents, younger and older adults. Addiction, 108(3), 592-599. https://doi.org/10.1111/add.12016

Fröolich, J., Lehmkuhl, G., Orawa, H., Bromba, M., Wolf, K., \& Dorten, A. G. (2016). Computer game misuse and addiction of adolescents in a clinically referred study sample. Computers in Human Behavior, 55(16), 9-15. https://doi.org/10.1016/j.chb.2015.08.043

Gentile, D. A., \& Anderson, C. A. (2006). Video games. Encyclopedia of Human Development, 3(8), 1303-1307.

Griffiths, M. D., \& Meredith, A. (2009). Videogame Addiction and its Treatment. Journal Contemp Psychother, 9(39), 247-253. https://doi.org/10.1007/s10879-009-9118-4

Griffiths, M. D. (2005). Components, model of addiction within a biopsychosocial framework. Journal of Subst Use, 


\section{0(4), 191-197. https://doi.org/10.1080/14659890500114359}

Hazar, Z. (2017). The Plague of the Age Digital Game Addiction and Coping Methods. Ankara: Gazi Kitabevi.

Hazar, Z., \& Hazar, M. (2017). Digital Game Addiction Scale for Children. Journal of Human Sciences. 14(1).

Hazar, Z., Hazar, M., \& Altun, M. (2016). Opinion For Parents of Children Ages 6-14 Digital Play Game. International Peer-Reviewed Journal of Communication and Humanities Research. July / August / September-Summer Semester Issue: 12 Year: 2016 Gel Code: M14-M19. https://doi.org/10.17361/UHIVE.20161222013

Hussain, Z., Williams, G. A., \& Griffiths, M. D. (2015). An exploratory study of the association between online gaming addiction and enjoyment motivations for playing massively multiplayer online role-playing games. Computers in Human Behavior, 50(15), 221-230. https://doi.org/10.1016/j.chb.2015.03.075

İşçibaşı, Y. (2011). Our Children Amidst Computer, Internet and Video Games. Selçuk Communication, 7(1), 122-130.

Karasar, N. (2000). Scientific Research Method (Concepts, Principles, Techniques)Ankara: Nobel.

Kars, G. B. (2010). The Effect of Violence Computer Games on The Attitude in Children. Master Thesis, Ankara University Institute of Health Sciences, Ankara.

Kneer, J., Rieger, D., Ivory, J. D., \& Ferguson, C. (2014). Awareness of Risk factors for digitalgame addiction: interviewing players and counselors. Int Journal of Ment Health Addiction 12(8), 585-599. https://doi.org/10.1007/s11469-014-9489-y

Landade, S., \& Roderisk, M. (2014). Recovery from addiction and the potential role of sport:Using a life-course theory to study change. International Review for the Sociology of Sport, 49(3/4), 468-484. https://doi.org/10.1177/1012690213507273

Lee, E., J. (2011). A case study of internet game addiction. Journal of Addictions Nursing, 22(3), 208-213. https://doi.org/10.3109/10884602.2011.616609

Lieberman, D. A., Fisk, M. C., \& Biely, E. (2009). Digital games for young children ages three to six: from research to design. Computers in the Schools, 26 (3), 299-313. https://doi.org/10.1080/07380560903360178

Miles, B. M., \& Huberman, A. M. (1994). Qualitative Data Analysis. Sage publitacions.

Müller, K.,W., Janikian, M., Dreier, M., Wölfling, K., Beutel, M. E., Tzavara, C., Richardson, C., \& Tsitsika, A. (2014). Regular gaming behavior and internet gaming disorder in European adolescents: results from a cross-national representative survey of prevalence, predictors and psychopathologicalcorrelates. Eur Child Adolesc Psychiatry, 24(3), 565-574.

Öztütüncü, D. F. (2006). New/Yeni Symposium Journal www.yenisymposium.net. Ekim. 161, 44(4).

Sarah, M. C, Laura M., Laura S. R. (2011). Game On. . Girls: Associations Between Co-playing Video Games and Adolescent Behavioral and Family Outcomes. Journal of Adolescent Health. 49(2011), 160-165. https://doi.org/10.1016/j.jadohealth.2010.11.249

Sarahan, B. M. (2015). A Guide for Qualitative Research Design and Practice. (Edit. Selahattin Turan). Ankara: Nobel.

Smith, G. (2004). How do computer games affect your children?. Eurasian Journal of Educational Research (EJER), $17(9), 72-80$.

Toran, M., Ulusoy, Z., Aydın, B., Deveci, T., \& Akbulut, A. (2016). Evaluation of Mothers' Views Regarding Children's Use of Digital Game. December-Vol:24 No:5 Kastamonu Education Journal.

Wallenius, M., \& Punamäki, R. L. (2008). Finnish longitudinal study on parent-child communication, sex, age and direct aggression. Journal of Applied Developmental Psychology. 29(4), 286-294.

https://doi.org/10.1016/j.appdev.2008.04.010

Yeltepe-Ercan, H. (2013). Exercise therapy in the treatment of addiction. Ankara: Nobel.

Yıldırım, H., \& Şimşek, A. (2012). Qualitative research methods in the social sciences. Ankara: Seçkin.

\section{Copyrights}

Copyright for this article is retained by the author(s), with first publication rights granted to the journal.

This is an open-access article distributed under the terms and conditions of the Creative Commons Attribution license which permits unrestricted use, distribution, and reproduction in any medium, provided the original work is properly cited. 